\title{
The Conflict Wings in the Saudi Political System
}

\author{
Abdullah Hazaa Othman ${ }^{1}$, Oleg Evgenievich Grishin ${ }^{1} \&$ Bakil Hasan Nasser Ali ${ }^{2}$ \\ ${ }^{1}$ Department of Political Analysis and Management, RUDN University, Moscow, Russia \\ ${ }^{2}$ Department of African and Arabic Studies, RUDN University, Moscow, Russia \\ Correspondence: Abdullah Hazaa Othman, RUDN University, 117198 Street Miklukho-Maklaya 13, Moscow, \\ Russia. E-mail: abdollah.othman1985@gmail.com
}

Received: July 21, 2020

doi:10.5539/jpl.v13n3p64
Accepted: August 3, $2020 \quad$ Online Published: August 17, 2020

URL: https://doi.org/10.5539/jpl.v13n3p64

\begin{abstract}
A marginal and bloody nature has characterized the struggle between the Saudi family members over the ruling regime since its first date. For the sake of governance, interests, and influence, alliances, disputes, and conflicts arose between the wings of the Saudi family and the liquidations that started since the establishment of Saudi Arabia and are still taking place today. King Abdulaziz liquidated leadership army, which contributed to the concentration of his rule, in the Battle of Al-Sabla. There is a conflict of wings between family members that reached the level of the coup, as happened with King Saud at the hands of his sisters, and to the killing, as happened with King Faisal at the hands of his nephew Faisal bin Musaed. The conflict and disagreement between the members of Al Saud have renewed since the first and second Saudi states and the current one. They expanded at present due to the abundance of money and influence by the control of a wing at the expense of other sides, the existence of a class between family members, and the secretion of the current conflict with the emergence of new leaders, the Saudi arena. The young men belong to the generation of the grandsons of the founding King, who eventually took control of the Saudi rule.
\end{abstract}

Keywords: conflict, Saudi Arabia, the ruling family, the third generation

\section{Introduction}

Conflict and competition for governance between members of the Al Saud family is not a new phenomenon, this conflict has become a prevalent phenomenon within the personalities of this family, and this conflict has renewed in each era for several reasons, including those related to the nature of the established genetic system, the quality of political traditions, and other rights due to a large number of members of this family, which varies in composition and complicates its structure. Motives for this conflict are almost constant, but they differ in their form and manifestations from one era to another.

Our understanding of the nature of the conflict within the ruling family in Saudi Arabia requires an awareness of the political framework in which it operates, so if we take into account the size of the ruling family, which estimates say includes between 3000 to 7000 prince of adulthood $^{1}$.It is natural for different directions and tendencies to emerge, and it is typical for each direction and its supporters to struggle with other instructions for power. We will clarify this research in three axes.

\section{Methodology}

The article relied on the historical method by listing past events in the struggle of the wings in the Saudi family and also relied on the descriptive approach by describing the internal conditions in the Saudi political system and reviewing them clearly and concretely and then studying the parties to the struggle for power in the Arab Kingdom.

The article also relied on the methodology of political systems theory, which studies the political process between a set of variables within the limits of societal and constitutional data, which leads to decision-makers in the Kingdom of Saudi Arabia.

\footnotetext{
${ }^{1}$ The story of political opposition in the oil kingdom. Al-Manar Magazine, Paris, page, 54 .
} 


\section{Main Part}

\subsection{The Historical Path in the Conflict of the Saudi Wings}

Our understanding nature of the conflict between the sons of King Abdulaziz and his grandchildren requires reference to the roots of this conflict and its early beginnings. From this standpoint, we will address in this dialogue the historical path of the conflict of wings from the founding of the first Saudi state to the establishment of the Kingdom of Saudi Arabia in the following manner:

The conflict is in the stage of establishing the first country where history indicates the struggle for power between members of the same family is not a modern phenomenon within the ruling family, as it is considered a rooted trait among members of this family, given the fact that the inception of the conflicts emerged since the founding of the first Saudi state, specifically with the death of Prince Saud bin Muhammad in the year 1726, where a violent conflict between his brothers and his cousins are on the rule of Diriyah. The matter culminated in the demise of one of his brothers, "Muqrin bin Muhammad," at the hands of his nephew Muhammad bin Saud, to make way for Zaid bin Farhan to control the rule of Diriyah ${ }^{2}$.

The rule of Al-Diriyah did not last for more than a year due to the weakness of his mismanagement, as the fate of his successors quickly met in the same year, and the judgment was then transferred to the nephew Muhammad bin Saud, "the founder of the first Saudi state" after a conflict between him and his sisters (Thunyan, Mashari, And Farhan). In 1726, utilizing power, Muhammad bin Saud managed to resolve the conflict and wrest rule from his brothers. Adad Diriyah rule lasted between (1726-1765), drawing on the power of the sword and the religion that provided him with the legal cover to extend his control over the rest of the island, where he led Muhammad bin Saud armies, conquering most parts of the region in the name of religion, establishing the first country to be known as the "first Saudi state," which during his rule became a significant military and religious force in the region.

In 1765, Muhammed bin Saud, the founder of the state, died, and after his death, the conflict erupted between his sons (Abdulaziz and Abdullah) over the ruling, and after an armed conflict between the two parties, Abdul Aziz managed to resolve this conflict, and he reigned until the year 1803, after which his son inherited the throne. Renowned as the only Saud and bearing the appellation "Saud the Great," he continued to rule until his death in 1818, and after his death, the offspring of Abdulaziz bin Muhammad Al Saud have cut off, and he (Abdullah bin Muhammad Al Saud) became Prince Saud's uncle and the second son of the founder. Abdullah Al-Diriyah ruled until the fall of the first Saudi state in 1819 at the hands of the Ottomans ${ }^{3}$

From the preceding, it has said that the period between (1727-1819), that is, the period during which the first Saudi state was born and collapsed was a period of political instability, resulting from the many conflicts within the Saudi house over governance and wealth, as no system worked to secure rotation of power. The ruling among the sons of the Al Saud family did not bring themselves to adhering to any existing conventional norms relating to inheritance. Any supposedly existing traditional laws concerning the question of inheritance have not implemented due to the heirs' propensity to act above the law. In the end, the conflict became the only method by which issues could resolve. Such a mechanism to resolve issues did not only have the detrimental effect of collapsing the first state but also left emotional implications that had a net effect on the second and third states, "the Kingdom of Saudi Arabia."

\section{The conflict between the sons of Faisal and the end of the second Saudi state}

After the collapse of the first Saudi state and the execution of its Emir Abdullah bin Muhammad Al Saud at the hands of the Othmans, the sons of Abdullah inherited rulership (Turki bin Abdullah and Sunyani bin Abdullah), while Sunyani was removed from power and died sterile. The ruling was then settled by Turki, who is considered the founder of the second Saudi state and his sons after him 4

Turki bin Abdullah ruled the second Saudi state, and as we mentioned earlier in two phases, the first stage in 1821, and the second stage begins from 1823 to 1834 , and during these two periods, a political and military struggle over the rule took place. This conflict occurred between Turki bin Abdullah Al Saud and Muhammad bin Mashari AL Muammar on the one hand and the Turkish and Othmani forces on the other. Turki bin Abdullah managed to recover his family's legacy of rule and founding the second Al Saud state, and the rule lasted until $1834^{5}$.

\footnotetext{
2 Fahd Al-Qahtani, The Wings Conflict in the Saudi Family, A Study of the Political System Since Establishment of the State, Al-Safa Publishing and Distribution, London, 1988, p,32.

${ }^{3}$ Fouad Ibrahim, Future of Saudi Arabia, Kitos House of Culture and Publishing, 2016, p. 79-80.

${ }^{4}$ Rima Muhammad, Al-Wajeez in the History of the Kingdom of Saudi Arabia, Modern Book Foundation, 2018, page, 97-98.

${ }^{5}$ Amin al-Rihani, History of Najd and its annexes, Al-Fakhriyah Publications, Riyadh, 1981, p,91-92.
} 
In that year, Turki bin Abdullah was subjected to an assassination attempt, organized by his nephew, the covetous ruler in the judgment, "Mashari bin Abdul Rahman," whose lineage goes back to the third son of Saud's first sons, Mesh. The latter ruled the emirate after the killing of Turki only forty days, when Faisal bin Turki revolted against his father killing Meshary and regaining the ruling again ${ }^{6}$

Moreover, the rule has settled by Faisal bin Turki, to whom the rulership of the third Saudi state is attributed, and his sons after him. Faisal bin Turki's rule (1834-1865) witnessed a type of political stability among family members, as competition and power struggles decreased during this period, as a result of Faisal's distribution of powers between him and his brothers (Galloway and Abdullah) ${ }^{7}$. However, this stability did not last long. Soon, the conflicts erupted once again, ravaging the stability and permanence of the state, this time between Prince Faisal's four sons (Abdullah, Saud, Muhammad, and Abdul Rahman), where Abdullah took over to succeed his father after his death in 1865 . He continued to rule until 1871 . His brother Saud turned against him after his alliance with a group of tribes of the region (Al-Murra, Ajman, and Al-Dawasir) against his brother, and the rule lasted for five years ${ }^{8}$.

In 1876 Abdullah was able to regain the rule a second time from his brother after he requested help from the Othmani, and Abdullah continued until 1889, after that, he died sterile, so the rule was then transferred to the third son (Muhammed bin Turki) who ruled the country for only two years, so that the rule would then be settled by Abdurahman Bin Faisal, father of King Abdulaziz bin Abdul Rahman bin Faisal Al Saud, founder of the Third Saudi State ${ }^{9}$.

It is worth noting that Faisal's sons 'struggle for power has caused the erosion of the Saudi state's structure and its collapse. In his struggle with his brother Saud, Abdullah bin Faisal used the Ottoman forces to extract the ruling from him, while the Othmani state found that this is sufficient justification for seizing the Al-Ahsa region and annexing it to Basra. On the other hand, the Al-Rashid family found that conflict as an opportunity to overthrow the government and grab it from the Al Saud family. After the battles between the two parties, the last of which was in 1891, known as the Mulaida incident ${ }^{10}$, As a result of that, Al-Rasheed managed to control Riyadh's rule and expel its last rulers from Al-Saud (Abdul Rahman bin Faisal), and his family displaced to the State of Kuwait ${ }^{11}$.

From the preceding, it said that struggle rule between members of the same family was inevitable, as the succession of a rule in the first and second Saudi states did not depend on any law or priority in order to the successor was determined, so the priority of birth (the succession of the eldest son after his father) has ignored. During that period, the parties to this family were not surprised to violate this rule even when they established the third state as we find that this rule did not have any consideration by the sons of Abdul Rahman bin Faisal, especially Abdul Aziz, who took the rule forcefully and basa in the face of his four brothers (Saad, Muhammad, Abdullah, Musaed) and his cousins Saud (Abdulaziz, Abdullah, Muhammad, and Saad) ${ }^{12}$.King Abdulaziz, at the beginning of his rule, undermined the chances of competitors emerging from the other families. He also rejected the principle of dividing the power with his cousins and did not rule out the use of force with them ${ }^{13}$.

In the end, Abdulaziz bin Abdul Rahman managed to resolve these conflicts and then established an equation of rule designed to monopolize the power and pass it on to his children and grandchildren after him, as he recognized the necessity of the caliphate according to the rule of birth that he set and is from (brother to brother) and not from father to son as it is. It is customary, and to secure the peaceful transition of the throne between the brothers, King Abdulaziz obligated his sons to follow this rule after him ${ }^{14}$

\footnotetext{
${ }^{6}$ Amin al-Rihani, History of Najd and its annexes, Al-Fakhriyah Publications, Riyadh, 1981, p,91-92.

${ }^{7}$ Abdul Rahman bin Abdulaziz Al-Hussain, Imam Turki bin Abdullah Al Saud efforts, Umm Al-Qura Magazine, No. $26,2004$.

${ }^{8}$ Encyclopedia of Desert Fighter, Saudi family, www.moqatel.com.

${ }^{9}$ Fahd Al-Qahtani, The Wings Conflict in the Saudi Family, A Study of the Political System Since Establishment of the State, Al-Safa Publishing and Distribution, London, 1988, p,38.

10 Battle of Al-Mleida, the Second Saudi State, 1891, Encyclopedia of Desert Fighter, http://www.moqatel.com/openshare/Behoth/Atrikia51/Saudia2/sec05.doc_cvt.htm

11 Abdel Fattah Hassan Abu Aliya, History of the Second Saudi State,2009, https://scholar.google.com/citations?user=sjrUNUgAAAAJ\&hl=en.

${ }^{12}$ Fahd Al-Qahtani, The Wings Conflict in the Saudi Family, A Study of the Political System Since Establishment of the State, Al-Safa Publishing and Distribution, London, 1988, p,33.

${ }^{13}$ Fouad Ibrahim, Future of Saudi Arabia, Kitos House of Culture and Publishing, 2016, p. 81.

${ }^{14}$ Suhair Abu Dawood, The Future of the Ruling Family in Saudi Arabia Between the Ma'rib Authority and the Aspirations of Wealth and Secular Religion, Arab Weekly Magazine, www.wikileaks-alarabia.com.
} 


\subsection{The Struggle of the Sons of King Abdulaziz bin Abdul Rahman}

After succeeding in extending his control over large parts of the Arabian Peninsula, King Abdulaziz strived to preserve his gains and single rule in the country, by undermining the opportunities of all competing parties from within and outside the family that could pose a threat to his powers ${ }^{15}$, and then set an equation designed to ensure the continuity of the ruling and the transfer of his children and grandchildren after him in a smooth manner, and this equation established as mentioned earlier ( The throne moves between the sons of the founding King, Abdulaziz bin Abdul Rahman, according to the priority of birth). However, the subsequent developments that have evolved over the composition and expansion of this family and the complexity of its structure, as well as the difference in social centers between its members, especially after the emergence of oil and its surplus returns, prevented adherence to this rule ${ }^{16}$.

Saud and Faisal conflict History indicates that the conflicts inside the Saudi House erupted after the death of King Abdulaziz in 1953, These conflicts centered between King Saud bin Abdulaziz, who succeeded his father, and his brother, Prince Faisal. This conflict reached its climax after 1958, as some voices emerged from within the ruling family, demanding King Saud bin Abdulaziz of the need to hand power to his brother, Crown Prince Faisa ${ }^{17}$. After a wave of internal and external pressures, Saud responded to the opponents 'voice and gave up his actual powers to his brother Faisal while retaining the title of King, but this concession did not put an end to the two brothers' conflict, as the dispute between them widened further, especially after 1960. Saud tried hard to restore prestige to himself, assuring everyone that he is the King, and he opposed all of his brother Faisal's decisions during his tenure as prime minister. The pushed Faisal to protest and resign in December 1960 together with his government. Saud formed a new government, and this government included the Prince Talal bin Abdulaziz, who did not last in this government for more than a year. In September 1961, a royal decree was issued declaring the exemption of Prince Talal bin Abdulaziz from his duties and the withdrawal of Saudi nationality from him, after his call for establishing a constitutional monarchy and cancel Dhahran base ${ }^{18}$.

During this period, after Talal bin Abdulaziz left the King Saud government, the Saudi family became divided into three conflicting wings:

1) The first wing has led by Saud and some supporters of the princes and tribesmen.

2) The second wing has led by Faisal bin Abdulaziz, a group of princes and a large number of clerics.

3) The third wing formed abroad, led by Talal bin Abdulaziz, with a group of princes known as (The Free Princes $)^{19}$

These parties continued to struggle until 1964, this conflict had its repercussions, as the state of the country deteriorated, and the structure of the Saudi family cracked. These reasons were sufficient for the people's meeting for the solution, which ultimately led to the contract of eminent princes and some clerics, and agrees that the only solution to this crisis would be to remove Saud from power and install Faisal in his place. On November 1, 1964, the judge of the Holy Land (Muhammad Ibrahim al-sheik) met with a group Among the scholars; they issued a fatwa dismissing Saud bin Abdulaziz from the government and pledging allegiance to his brother Faisal, the King of the Kingdom of Saudi $\mathrm{Arabia}^{20}$.

During his tenure as Faisal bin Abdulaziz, he managed to achieve wide-ranging economic and social development. In his reign, Saudi Arabia became a robust central state with a capable administrative apparatus. Saudi Arabia witnessed a kind of political stability ${ }^{21}$.

However, despite this stability that Saudi Arabia witnessed during Faisal's rule, it does not mean that the conflict had ended. Still, on the contrary, the conflict had shifted from the public side to the hidden side. The motives of the revolt erupted, the difference, and the desire to ascend to the throne ${ }^{22}$, This hidden side was quickly exposed on March 25, 1975, after Faisal bin Musaed assassinated his uncle, King Faisal bin Abdulaziz, in his office. During

${ }^{15}$ Rashid Rida, the story of the political opposition in the oil kingdom, Al-Manar Magazine, counter 11,1985,p,54.

${ }^{16}$ Muhammad Ali Tamim, Wings Conflict in the Saudi Royal Family, Tikrit University Journal for Humanities, Issue 4, 2003,p,329-330.

17 Vasiliev, History of Saudi Arabia, Dar Al-Takadum, 1986, p. 439.

${ }^{18}$ Muhammad Ali Tamim, Wings Conflict in the Saudi Royal Family, Tikrit University Journal for Humanities, Issue 4, 2003 ,p,231

${ }^{19}$ Middle East Record, Jerusalem 1960, No,1-2,p.420.

${ }^{20}$ Gary Samuel Samore, Royal Family Politics in Saudi Arabia 1953-1982. doctoral dissertation, Cambridge, Massachusetts (Harvard University, 1983), P,185-178

${ }^{21}$ Tim Niblock, Saudi Arabia: Power Legitimacy and Survival Routledge,2006, see Http://dannyreviews.com/h/saudi_Arabia.html.

${ }^{22}$ Widad Khudair, King Faisal's position on the issues of Yemen and Palestine, Doctor's thesis submitted to the Faculty of Arts, Basra University, 1997,p,68-70. 
his meeting with Kuwaiti Oil Minister Abdul-Muttalib Al-Kazemi. There are numerous accounts of the cause of this incident, which was called the "palace coup," there are many accounts and speculation in the assassination that it is not without the stamp of revenge against the regime, especially after making sure that the perpetrator was inclined to another camp or had strong relations with wings hostile to the Faisal wing, as well as the relationship of kinship that linked Faisal bin Musaed to the Al Rashid family from the mother's side ${ }^{23}$

Second, the struggle of the Sudairi wing Faisal's bloody end, or as some people call it, was the "palace coup." It is the beginning of a new phase, the most important of which is the emergence of forces on the battlefield. The other parties competed on the throne, and the Sudairi wing represented this power. Furthermore, it made Sidrun control the most critical positions in the Kingdom, as this period that started in 1975 witnessed an apparent Sudairi excitement of the positions ${ }^{24}$. The seven (Al-Sudairain) and they (Fahd bin Abdulaziz, Sultan bin Abdulaziz, Nayef bin Abdulaziz, Salman bin Abdulaziz, Abdul Rahman bin Abdulaziz, Ahmed bin Abdulaziz, and Turki bin Abdulaziz) dominated the most critical positions in the state. There were numerous and long-standing conflicts between this wing and the rest of the family's branches. Initially, the family of the two Sudaires tried during the period of King Khalid's rule, which spanned from 1975-1982, to weaken the wing of Abdullah bin Abdul Aziz, who used to be the head of the National Guard, and there were attempts to remove him from office and strip him of all the forces that keep him in the competition. However, these attempts did not bear fruit, especially after Muhammad Abu Sherin (King Khalid's brother) stood by Abdullah bin Abdulaziz and prevented them from obtaining this order to prevent the (Al-Sudairain) authority from unifying itself ${ }^{25}$.

Sudairi wing did not stop in its attempts and the conflict with competitors, as the conflict between it and the wing of Abdullah bin Abdulaziz intensified more especially after the death of Khalid and the ascension of Fahd to the throne of the Kingdom in 1985 to succeed his brother Khaled, as Abdullah, who took over the reign of the Covenant at the time, worked hard to isolate his brother Fahd on the throne of the Kingdom. However, he ultimately failed, because his seven brothers surrounded Fahd bin Abdulaziz. Despite Fahd's illness and his inability to manage governance affairs, his Sudairian insisted on staying on the throne. They struggled without transferring his powers to his Crown Prince Abdullah until he died in $2005^{26}$, On August 1, 2005, Abdullah bin Abdulaziz finally managed to ascend to the throne of the Kingdom of Saudi Arabia to succeed his brother, Fahd, while Sultan bin Abdulaziz was named crown prince, and since he assumed the throne of the Kingdom, King Abdullah worked hard to weaken the wing (Sudairi), so he set new rules for the transfer of power aimed mainly to break the Sudairin monopoly of power after him ${ }^{27}$.

It said that during the reign of King Abdullah bin Abdulaziz (2005-2015), a committee was established, known as the Allegiance Commission, headed by Prince Mishaal bin Abdulaziz, and it included 34 members from the $\mathrm{Al}$ Saud family and this commission based on determining who takes over the reign of the Covenant after the death of the King according to the conditions set. It is worth noting that the work of the commission during that period was fictitious and has no role in the future, as the crown prince has set and ended the matter, and the aim of establishing the commission of allegiance is to weaken the Sudairi wing from assuming power. In addition to the issuance of many appointments, which created a kind of internal balance of power between the competitors' King Abdullah bin Abdulaziz and Crown Prince Nayef bin Abdulaziz, the matter did not last for long. After the death of Naif June 16, 2012, the balance of the internal forces subjected to a significant imbalance and the rise of other Sudairi parties to the circle of conflict and confrontation. On the same day, a royal decree issued stipulating the appointment of Prince Salman bin Abdulaziz as Crown Prince, and Prince Ahmed bin Abdulaziz as Minister of Interior, which it is worth noting that Ahmed Bin Abdulaziz did not hold this position for more than a year, so he was quickly relieved under a royal order issued on November 5, 2012. Muhammad bin Nayef appointed in his place, and Muhammad bin Nayef was the closest to Abdullah's wing. As for the second reason, it is that the figure of Muhammad bin Nayef was one of the most agreed-upon figures in the American circles, especially concerning aspects of joint coordination to combat terrorism ${ }^{28}$.

\footnotetext{
23 Muhammad Al-Tahir, by what guilt did he kill the King? Journal article published channel 2016/7/20 RT Arabic, https://arabic.rt.com/news/833050

${ }^{24}$ Abdul Mohsen Hilal, The need for reform in Saudi Arabia, Center for Arab Novel Studies, 2014,p,58.

${ }^{25}$ Fouad Ibrahim, Future of Saudi Arabia, Kitos House of Culture and Publishing, 2016, p. 84

${ }^{26}$ Rachel Bronson, How to understand the US-Saudi relations, in a group of authors: Saudi Arabia in the balance, Center for Arab Unity Studies, Beirut, 2012,p,243.

27 Asma Sharif, a senior Saudi prince resigns from the Allegiance Commission, Reuters, November 16, 2011, http://ara.reuters.com/article/topNews/idARACAE7AF0NO20111116.

${ }^{28}$ Fouad Al_Ibrahim, Undermining the Sudairi Clan: The Kink manages the power Struggle, Al-Akbar English, 16/5/2014, $<$ http://english alakbar.com/node/197987,last accessed February 6, 2015
} 
Finally, the rise of Prince Salman bin Abdulaziz during the reign of the era was a good start for a new phase of the power struggle. The royal decrees issued during this stage confirmed conclusively King Abdullah's attempt to prevent any monopoly of power by the Sudairians in the future. Among these decisions are:

The first decision, on May 27, 2013, a royal decree was issued to convert the National Guard Foundation into a ministry to be assumed by Prince Miteb bin Abdullah (the son of the elder King). Abdullah found the decision was trying in all ways to push his son Miteb to the forefront. Having appointed him Minister, he secured an opportunity for him to reach the throne of the Kingdom in the future ${ }^{29}$.

The second decision, on March 27, 2014, a royal decree was issued appointing Prince Muqrin bin Abdulaziz (Deputy Crown Prince or King if the positions of the king and crown prince are vacant at one time and it is not permissible in any case to amend this order or replace it in any form or from any person). This decision has other implications, as it prevents the next King, Salman bin Abdulaziz if he ascends to the throne from any attempt to change it, and then becomes Muqrin crown prince and binding after the death of Abdullah.

It said that these changes made by King Abdullah during his reign were in themselves an indicator of the power struggle, as it aims to weaken the Sudairi wing and undermine an opportunity on the one hand. On the other hand, it aims to make room for other personalities loyal to him to guarantee stable positions in the line of heredity. Notwithstanding, we find these attempts did not bear fruit, as the Sudairi wing's persistence overcame Abdullah's will and attempts. The wing quickly rose and restored control over the government throne of the Kingdom, especially after the death of King Abdullah and the rise of his Crown Prince Salman to the throne of the Kingdom in Canon The second of $2015^{30}$.

\subsection{The Struggle between the One Wing and the Rise of the Third Generation}

The era of King Salman bin Abdulaziz who succeeded his late brother Abdullah bin Abdulaziz in January 2015, is considered one of the most rapid and radical covenants in resolving conflicts. Within a few days of his accession to the throne, the events of King Salman bin Abdulaziz took rapid and sudden changes that affected the structure of the authority and its people. The first of these changes was to enable the sons of the third generation (the generation of grandchildren) to occupy essential positions that enable them to compete for the throne of the Kingdom in the future ${ }^{31}$.

In the early hours of his accession to the throne of the Kingdom of Saudi Arabia, King Salman bin Abdulaziz issued a set of royal orders, among which was the appointment of Muhammad bin Nayef, Deputy Crown Prince Muqrin bin Abdulaziz, while retaining the position of Minister of Interior who inherited it from his father, Prince Nayef, and King Salman appointed his younger son. Prince Muhammad bin Salman, Minister of Defense and Head of the Royal Court, and these appointments had profound implications, the first of which is that the process of transferring power to the third generation has formally completed and the second indication is that these changes pave the way for enabling the Sudairi wing over all state institutions, with the prospect of marginalization of other wings. The competition confined to the Sudairi Wing. On April 29 of the same year, i.e., one day after these appointments passed, the second batch of royal orders was issued, and these orders almost completely changed the structure of the authority, It read as follows ${ }^{32}$ :

The first area (inheritance): where King Salman exempted his brother Prince Muqrin bin Abdulaziz from the mandate of the Covenant and replaced by Prince Muhammad bin Nayef, and Muhammad bin Nayef is considered the first prince of the generation (the grandchildren) to occupy this position, as Prince Muhammad bin Salman appointed a deputy guardian Al-Ahd and head of the Royal Court and the Shura Council for Economic and Development while retaining the Ministry of Defense, and the appointment of Muhammad bin Salman in this position was categorically indicating the large amount of support received from his father to reach the throne in the future.

As for the second area, it is (foreign policy). King Salman removed Foreign Minister Saud Al-Faisal and replaced by Adel Al-Jubeir. The appointment of Al-Jubeir in this position was of great importance to King Salman. He wants to have a voice in Washington after the tensions between the two countries in President Obama's era. Against

\footnotetext{
${ }^{29}$ Al-Riyadh newspaper, Saudi Arabia, the counter, 16409, and May 28, 2013.

30 Yoel Guzansky, Saudi Arabia After Abdullah, The Institute for National security Studies Strategic(INSS Insight), 2015/1/13. http://www.inss.org.il/publication/saudi-arabia-after-abdullah

${ }^{31}$ Saudi Responses to the King's Decisions, Middle East Monito,30 January2015,http://www.middleeastmoaitor.com/201530-saudi-ersponsesto-the-king-decisions(last accessed by September 14, 2014.

32 Glen Carey and Wael Mahdi, Saudi King Cements Power Around Next Generation in Reshuffle, Bloomberg, April 29, 2015, see, http://www.bloomberg.com/news/articles/2015-04-29/saudi-king-names-mohamed-bin-nayef-as-crown-prince-i92316xu.
} 
the background of the US administration's positions during his term on the events in Syria, the Arab Spring, and the Iranian nuclear agreement.

On the one hand, these decisions issued by King Salman during the day he assumed the throne formed an internal and external shock, and they described as an earthquake or a soft coup against his brother and his previous policies $^{33}$, When reviewing these decisions and the time of their issuance, many results, the most important of them observed:

The decision removed Prince Muqrin from the reign of the Covenant and replace it with Prince Muhammad bin Nayef is a violation of the rules of succession in the Kingdom that gives priority to the sons of the founding King (the rule transferred between the sons of the founding king), the ruling passed to the generation of grandchildren in light of an apparent marginalization of the sons of the founding King who are still on Alive, including Prince Ahmed bin Abdulaziz, and Prince Talal bin Abdulaziz.

These decisions are indication conflict in a speed of which the decisions of appointment and exemption issued in the first days of the accession of Salman to the throne, which affected the mandate of the Covenant and the Ministry of Foreign Affairs, revealed the depth of the dispute between Salman and his brother, the former King Abdullah, these changes prepared in advance of the death of King Abdullah.

Through these decisions, King Salman sought to restructure the government and radically modified the rules of succession that have prevailed for decades, according to which power distributed and shared with other family branches. It is limited to the authorities in a few categories, most of which belong to the third generation (the grandchildren) of the two Sudaires and those close to Salman and his son ${ }^{34}$.

From the above, it said that King Salman during this period succeeded in resolving the equation of the struggle for power in favor of the two Sudaires, but at the same time, his recent decisions led to the emergence of a new dualism over the authority other than the known sons (Saud, Faisal) and (Fahd, Abdullah). It is the dualism of the grandchildren or the dualism of the third generation that brought together the two princes (Muhammad bin Nayef and Muhammad bin Salman). And both of them became closer to the throne of the Kingdom after marginalizing the leading competitors and the weakness of other wings and the absence of strong sons.

Indeed, signs of rivalry appeared between the two princes early on, as the period between the years (2015-2017) witnessed a public conflict between Prince Muhammad bin Nayef and Prince Muhammad bin Salman, Ibn Salman took advantage of his father's unlimited support to overcome all opponents and competitors, including Prince Muhammad bin Nayef, who was called "the man of darkness" inside Saudi Arabia and "Prince of Combating Terrorism" in the Western media because of his security successes and achievements ${ }^{35}$.

Ibn Nayef's accomplishments and his fame represented one of Ibn Salman's obstacles to reaching the throne, so he had to bypass his cousin Prince Muhammad bin Nayef to rule his grip on the throne, and on the previous basis, the young Prince Muhammad bin Salman swiftly pushed enormously to implement his plans to control all the joints of the state and its institutions exploiting The great support he received from his father. The ambitious prince walked according to many directions, which are all the following:

The first trend: controlling the decision-making circles in the Kingdom, and this was taken over by assuming the chairmanship of the (ARMCO) Oil Company, which is the largest oil company in the world owned by Saudi Arabia, Then he assumed the Ministry of Defense and the presidency of the royal court and was appointed head of the Council for Economic Affairs and Development, and a second deputy prime minister (the King), that these significant responsibilities that were given to Prince Muhammad bin Salman made him control most of the decision-making wheels in the Kingdom, leaving him with only the interior portfolio that It is assumed by Prince Muhammad Nayef, and the National Guard, which is headed by Prince Mutaib, son of the late King Abdullah bin Abdul Aziz, and possession in his control of all the reins of the Kingdom ${ }^{36}$.

The second trend has represented by the international presence and successive visits to the West's countries, especially the United States of America. Ibn Salman took advantage of Crown Prince Muhammad bin Nayef's isolation from the outside world and the press. His preoccupation with the Kingdom's internal security tasks and

\footnotetext{
${ }^{33}$ David Hearst, A Saudi Palace Coup, Huffing Post, January 23, 2015, see, https://www.huffingtonpost.com/david-hearst/a-saudi-palacecoup_b_6531246.html, (last accessed mar 25,2015

${ }^{34}$ Mohamed Nabil Mellin, Establishing a Vertical Authority: The Roots and Functions of the Conflict on the Saudi Throne, Al-Jazirah Center for Studie $10 / 7 / 2017, \mathrm{p}, 4$, http://studies.aljazeera.net.

${ }^{35}$ Fouad Ibrahim, Future of Saudi Arabia, Kitos House of Culture and Publishing, 2016, p. 114.

${ }^{36}$ Abdullah Al-Shayji, Saudi-American relations during the reign of King Salman, in the Molven Group: Saudi Arabia's foreign policy prospects during the reign of King Salman bin Abdulaziz. Middle East Studies Center 2015, p,19-30.
} 
confronting terrorism, to carry out a marketing campaign for himself outside Saudi Arabia, as it witnessed the year 2016,2017 many visits to Crown Prince Mohammed bin Salman to the United States of America. The aim of these visits was precise and is the need to establish support for him inside the White House, and to highlight himself as a new face of the Kingdom or as a potential king after his father, To this end, Prince Muhammad bin Salman used many American pressmen and writers to polish his image and show himself as a liberal revolutionary king aiming to transfer the Kingdom from the circle of tradition to the circle of modernity and openness to the outside world. Indeed, this trend received considerable attention from some American officials, especially President (Donald Trump $)^{37}$

The third trend: reducing the powers of the Minister of Interior (Crown Prince) Prince Muhammad bin Nayef AlMitwalli for security affairs in the Kingdom, After Ibn Nayef's reputation and his broad security authorities, became one of the obstacles that confronted Muhammad bin Salman; therefore Ibn Nayef must be bypassed and besieged internally and stripped of all of his powers, so Muhammad bin Salman issued a set of orders deciding the establishment of the (National Security) apparatus, which competes by nature The Ministry of Interior and the Political and Security Affairs Council chaired by Prince Muhammad bin Nayef. This body directly linked to the royal court, which is under the authority of Muhammad bin Salman ${ }^{38}$.

Not only was the siege of Ibn Nayef internally, but Ibn Salman also went to his attack externally, Khalid bin Salman, brother of Muhammad bin Salman was appointed a Saudi ambassador to the United States of America, and the mission of this ambassador, as he put an end to Ibn Nayef's relations with the Americans and cut the road on him on the one hand, And to direct attention to Mohammed bin Salman, while ensuring his direct contact with the American administration, on the other side.

These decisions and appointments had a clear indication, which is that Prince (Mohammed bin Salman) seeks to establish a vertical authoritarian regime with the support of his father, King Salman, while surrounding him with a vast network of loyalists, especially from the young generation, with an evident marginalization of other parties, including the Prince (Muhammad Nayef) He stripped off all his powers. He was awaiting the final order to lay down the fate of his predecessor from his cousins, to be enslaved entirely from competing to the throne. In late June 2017, a royal decree issued whereby Crown Prince Muhammad bin Nayef was exempted from the mandate of the Covenant and stripped of all of his powers. Prince Muhammad bin Salman was appointed in his place ${ }^{39}$.

After Bin Nayef left the circle of conflict, there remains a question: Is the conflict inside the Saudi house over, and is the matter resolved in favor of Ibn Salman? The answer to that is, of course, no, as Ibn Salman's struggle with his rivals did not end but somewhat extended to other parties other than princes such as technocrats, people in business, and clerics. As long as three groups represented an obstacle to his direction development projects, he adopted and promoted before and after his rise to the Covenant mandate. especially the clerics as the most conservative group in the Kingdom.

\section{Conclusion}

After completing this research, we must mention the most relevant results, and accordingly, what has reached through this research is as follows;

The Saudi regime in its various stages suffers from problems related to the succession agent or the process of transferring power, and this problem is caused by the lack of a stable system of Saudi rule to determine the process of selecting the ruler, despite the presence of a text in the Saudi Basic Law of Governance specifying who assumes the reigns is as stated in The fifth article of it (the ruling will be in the sons of the founding King Abdulaziz bin Abdul Rahman Al-Faisal Al Saud and the sons of the sons assume leadership by pledging to the book of God and the Sunnah of His Messenger) but this article suffers from a lot of ambiguity and disagreement as it did not meet the conditions required by the ruler.

However, this is what made the process of transferring power in Saudi Arabia complicated, marred by many problems and disputes. Hence, many conflicts arose with each transfer of power due to this system's lack of clear rules regulating this process. These conflicts have increased with every process of transfer of power due to the lack of this system. Clear rules regulate this process, and these conflicts have increased further with the emergence of

\footnotetext{
${ }^{37}$ Mark Mazzetti and Ben Hubbard, Rise of Saudi Prince Shatters Decades of Royal Tradition, The New York Times, Oct,15,2016), see, https://www.nytimes.com/2016/10/16/world/rise-of-saudi-prince-shatters-decades-of-royal-tradition.html?

${ }^{38}$ Fahd Al-Qahtani, The Wings Conflict in the Saudi Family, A Study of the Political System Since Establishment of the State, Al-Safa Publishing and Distribution, London, 1988, p,32.

${ }^{39}$ Amjad Ahmad Jibril, What Happens in Saudi Arabia: Foreign Policy Between Continuity and Change, A study issued by the Adrak Center for Studies and Consultation, October 11, 2017.
} 
the third generation, which in recent times has been competing intensely for the throne ranks in the Kingdom of Saudi Arabia.

During the recent epochs, the Saudi regime witnessed political changes, and these variables have a clear transgression of the traditions and rules of succession recognized in the Kingdom of Saudi Arabia. It intimated that the mandate of the Covenant is between the sons founding King and from brother to brother.

During the recent period, especially after Prince Muhammad bin Salman took over the Charter, the conflict in Saudi Arabia expanded to include other parties, this time alongside the royal family, after the conflict with Ibn Salman's cousins ended, he faced from the pillars of the Saudi regime that granted him the Sharia, a religious wing, It is similar to establishing King Abdulaziz bin Abdul Rahman's conflict with a group of ideological brothers who violated Abdel Aziz's inclinations for religious reasons, and this was in the beginning in his endeavor to build a Saudi state, as both clashes have the same reasons and goals, as we see that Ibn Salman, in his struggle with The religious establishment, is trying to break the burden of this institution as part of its efforts to build his country a system compatible with Western will.

\section{References}

Abdel, F. H. A. A. (2009). History of the Second Saudi State. Retrieved from https://scholar.google.com/citations?user=sjrUNUgAAAAJ\&hl=en

Abdul, M. H. (2014). The need for reform in Saudi Arabia. Center for Arab Novel Studies.

Abdul, R. A. A.-H. (2004). Imam Turki bin Abdullah Al Saud efforts. Umm Al-Qura Magazine, (26).

Abdullah, A.-S. (2015). Saudi-American relations during the reign of King Salman, in the Molven Group: Saudi Arabia's foreign policy prospects during the reign of King Salman bin Abdulaziz. Middle East Studies Center.

Al-Riyadh newspaper, Saudi Arabia, the counter, 16409, and May 28, 2013.

Amin, A.-R. (1981). History of Najd and its annexes. Al-Fakhriyah Publications, Riyadh.

Amjad, A. J. (2017). What Happens in Saudi Arabia: Foreign Policy Between Continuity and Change, a study issued by the Adrak Center for Studies and Consultation.

Asma, S. (2011). A senior Saudi prince resigns from the Allegiance Commission. Reuters. Retrieved from http://ara.reuters.com/article/topNews/idARACAE7AF0NO20111116.

Battle of Al-Mleida, the Second Saudi State. (1891). Encyclopedia of Desert Fighter. Retrieved from http://www.moqatel.com/openshare/Behoth/Atrikia51/Saudia2/sec05.doc_cvt.htm.

David, H. (2015). A Saudi Palace Coup, Huffing Post. Retrieved from https://www.huffingtonpost.com/davidhearst/a-saudi-palace-coup_b_6531246.html

Fahd, A.-Q. (1988). The Wings Conflict in the Saudi Family, A Study of the Political System Since Establishment of the State. Al-Safa Publishing and Distribution, London.

Fouad, A. I. (2014). Undermining the Sudairi Clan: The Kink manages the power Struggle. Al-Akbar English. Retrieved from http://english al-akbar.com/node/197987

Gary, S. S. (1983). Royal Family Politics in Saudi Arabia 1953-1982. Doctoral dissertation, Cambridge, Massachusetts. Harvard University.

Glen, C., \& Wael, M. (2015). Saudi King Cements Power Around Next Generation in Reshuffle. Bloomberg. Retrieved from http://www.bloomberg.com/news/articles/2015-04-29/saudi-king-names-mohamed-binnayef-as-crown-prince-i92316xu

Mark, M., \& Ben, H. (2016). Rise of Saudi Prince Shatters Decades of Royal Tradition. The New York Times. Retrieved from https://www.nytimes.com/2016/10/16/world/rise-of-saudi-prince-shatters-decades-of-royaltradition.html

Mohamed, N. M. (2017). Establishing a Vertical Authority: The Roots and Functions of the Conflict on the Saudi Throne. Al-Jazirah Center for Studie. Retrieved from http://studies.aljazeera.net

Muhammad, A.-T. (2016). By what guilt did he kill the King? Retrieved from https://arabic.rt.com/news/833050

Rashid, R. (1985). The story of the political opposition in the oil kingdom. Al-Manar Magazine, (11).

Rima, M. (2018). Al-Wajeez in the History of the Kingdom of Saudi Arabia. Modern Book Foundation.

Saudi Responses to the King's Decisions. (2015). Middle East Monito. Retrieved from http://www.middleeastmoaitor.com/201530-saudi-ersponses-to-the-king-decisions 
Yoel, G. (2015). Saudi Arabia After Abdullah, The Institute for National security Studies Strategic. Retrieved from http://www.inss.org.il/publication/saudi-arabia-after-abdullah

\section{Copyrights}

Copyright for this article is retained by the author(s), with first publication rights granted to the journal.

This is an open-access article distributed under the terms and conditions of the Creative Commons Attribution license (http://creativecommons.org/licenses/by/4.0/). 